\title{
Child Labor and Poverty Reduction in Vietnam: Issues and Policy Implications
}

\author{
Khuyen Hoang Kim \\ Vietnam Academy of Social Sciences, Vietnam \\ Nguyen Thu Dung* \\ Vietnam Academy of Social Sciences, Vietnam
}

\begin{abstract}
There is a relationship between child labor and poverty. The unaffordable financial state of households is the main reason to force children to become workers at an early age. One of the main points to respond to eliminating and preventing child labor is how to reduce poverty. Accordingly, many legal tools are designed and applied, such as finance supports or vocational training programs. This study provided practical evidence on the link between child labor and poverty in Vietnam as well as analysis on which legal measures the Vietnamese Government has done to tackle child labor based on the poverty approach, and then some recommendations will be mentioned to eliminate child labor, especially in the context that negative impacts of COVID-19 pandemic push children to fall into poverty again and force them to continue to work in early-stage in most countries in the world, including Vietnam. The study used a qualitative approach, including on desk review and a second-date analysis on regulations on child labor and poverty reduction policies in Vietnam. This study found that there existed a gap between policies on poverty to reduce child labor and practices. Comprehensive approaches in making policies, as well as law enforcement, are the core reasons. The gap should be overcome by providing unified action plans done by an effective governmental authority system.
\end{abstract}

KEYWORDS: Child Labor, Children Rights, Poverty Reduction.

Copyright $@ 2021$ by Author(s)

This work is licensed under a Creative Commons Attribution-ShareAlike 4.0 International License. All writings published in this journal are personal views of the authors and do not represent the views of this journal and the author's affiliated institutions.

HOW TO CITE:

Kim, Hoang Khuyen \& Nguyen Thu Dung, "Child Labor and Poverty Reduction in Vietnam: Issues and Policy Implications" (2021) 8:3 Lentera Hukum 471-502. DOI: <https://doi.org/ 10.19184/ejlh. v8i3.25777>.

Submitted: 26/07/2021 Reviewed: 10/09/2021 Revised: 13/11/2021 Accepted: 26/11/2021

* Corresponding author's e-mail: zzung3385@gmail.com 


\section{INTRODUCTION}

Child labor is a widespread phenomenon in developing nations as well as underdeveloped countries. Sub-Saharan Africa was the region with the highest rate of child labor, and it was over ten times higher than the rate of Euro and North America. ${ }^{1}$ It has been prevalent that children should do housework or do some economic activities suitable for their motion and physical development. However, the overload of working hours and unsafe working conditions in child labor has made it a type of abuse and exploitation of children. It is considered to infringe on human rights so that many countries banned it.

Historically, child labor exploitation has been associated with industrial revolutions. ${ }^{2}$ They are reminded to remember one of the typical images of child exploitation is that of a boy who was suffocating on a chimney or with small hands working at the relentless pace of a machine. ${ }^{3}$ Since the 1990s, there has been a turning point in the role of children as laborers. There is no place for child labor in society, and it robs children of their future and keeps families in poverty. ${ }^{4}$ It is estimated that about 152 million from 5 to 17 years old are engaged in labor or nearly one-tenth of all children worldwide. ${ }^{5}$ The rate of child laborers is still high even though countries are constantly trying to prevent and gradually eliminate them during the past 20 years. $^{6}$

Although there are many reasons, they originated child labor, such as lack of social protection, limited awareness of parents, children, and employers.

1 ILO \& UNICEF, Child Labour: Global Estimate, Trends and the Road Forwards (2020).

2 Colin Heywood, A History of Childhood: Children and Childhood in the West from Medieval to Modern Times (John Wiley \& Sons, 2013).

3 Ibid.

4 International Labour Organization, "2021: International Year for the Elimination of Child Labour", online: <https://www.ilo.org/global/about-the-ilo/newsroom/news/ WCMS_766351/lang--en/index.htm>.

5 International Labour Organization, "Modern slavery and child labour - 40 million in modern slavery and 152 million in child labour around the world", online: <https:// www.ilo.org/hanoi/Informationresources/Publicinformation/newsitems/WCMS_57 4717/lang--en/index.htm>.

6 International Labour Organization, supra note 4. 
Many studies showed a relationship between child labor and poverty. The unaffordable financial state of households is the main reason to force them to become workers at an early age. ${ }^{7}$ Poor parents tend to force their children to work instead of going to school. ${ }^{8}$ In addition, the cost of attending school is relatively high, which makes parents cannot afford to pay tuition fees. As a result, living in poverty makes them have no opportunities to access education services. Moreover, poverty also has negative impacts on the basic rights of children, such as enjoying the best life, equity in accessing social protection services.

Currently, in the context of the COVID-19 pandemic, it has made poverty more severe and increasing child labor. In Vietnam, according to statistics, about 4-5 million workers have lost jobs. ${ }^{9}$ Although Vietnam's economy has been growing, it is undeniable that COVID-19 has negatively impacted households in the long term. The income of $45 \%$ of households has been decreased in the first half of January 2021, compared to January $2020 .{ }^{10}$

The authorities have designed many laws to address this issue through financial supports or vocational training. However, the enforcement of such policies to reduce poverty has remained to be a challenge in many countries, including Vietnam. Therefore, it is necessary to describe the link between child labor and poverty in Vietnam and analyze legal measures that the Government of Vietnam has taken to tackle child labor issues by reducing poverty. The research questions of this study include: (1) how is the link between child labor and poverty in Vietnam? (2) Which are legal measures to reduce poverty for eliminating child labor? (3) What solutions should be mentioned?

7 UN Committee on the Rights of the Child (CRC), Report of the UN Committee on the Rights of the Child: fourth session (September 20 to October 8, 1993), October 25, 1993, $C R C / C / 20$ (1993).

8 Ana C Dammert, et al., Effects of Public Policy on Child Labor Current Knowledge, Gaps, and Implications for Program Design (Research Support Team).

9 Tran Nguyen Quang Ha, "The Impact Of Covid_19 On Child Labor In Vietnam" (2021) 24(3) Science \& Technology Development Journal 2044-2048.

10 Ibid. 


\section{METHODS}

This study used the qualitative approach, including on desk review and a second-date analysis on regulations on child labor and poverty reduction policies in Vietnam. It is often justified as legal research because it referred to some legal references in analyzing the issue, in addition to its dependence on library resources. In so doing, it referred to the data from the National Survey on Child Labor by ILO combined with the General Statistics Office and the Ministry of Labor, War Invalids, \& Social Welfare of Vietnam in 2018 and some other social surveys to provide some practical evidence on the link between poverty and child labor in Vietnam. These sources contributed to analyzing the successes and limits of Vietnamese regulation on reducing poverty to eliminate child labor.

\section{CHILD LABOR AND ITS LINKAGE TO POVERTY}

\section{A. Situation of Child Labor in Vietnam}

Child labor becomes one of the crucial challenges in many developing countries, including Vietnam. A national child labor survey conducted in 2018 in Vietnam showed a downward in child labor, but the rate is still high in the Asian area. About 1,754,066 children engaged in economic activities, accounting for $9.1 \%$ of total children from 5 to 17 years old, while the rate in 2012 was $15.5 \% .{ }^{11}$ The rate was lower than the world's average rate $(9.6 \%$ in 2016$)$ but much higher than in Asia and the Pacific (7.4\% in 2016). ${ }^{12}$ Specifically, it was approximately $1,031,944$ children defined as child labor, accounting for $58.8 \%$ of total children engaging in economic activities. ${ }^{13}$

11 International Labor Organization, General Statistic Office \& Ministry of Labor, War Invalids and Social Affairs, Vietnam National Child Labour Survey 2018 - Key Findings (2020).

12 ILO, Global Estimates of Child Labor (2017).

13 International Labor Organization, General Statistic Office \& Ministry of Labor, War Invalids and Social Affairs, supra note 11. 


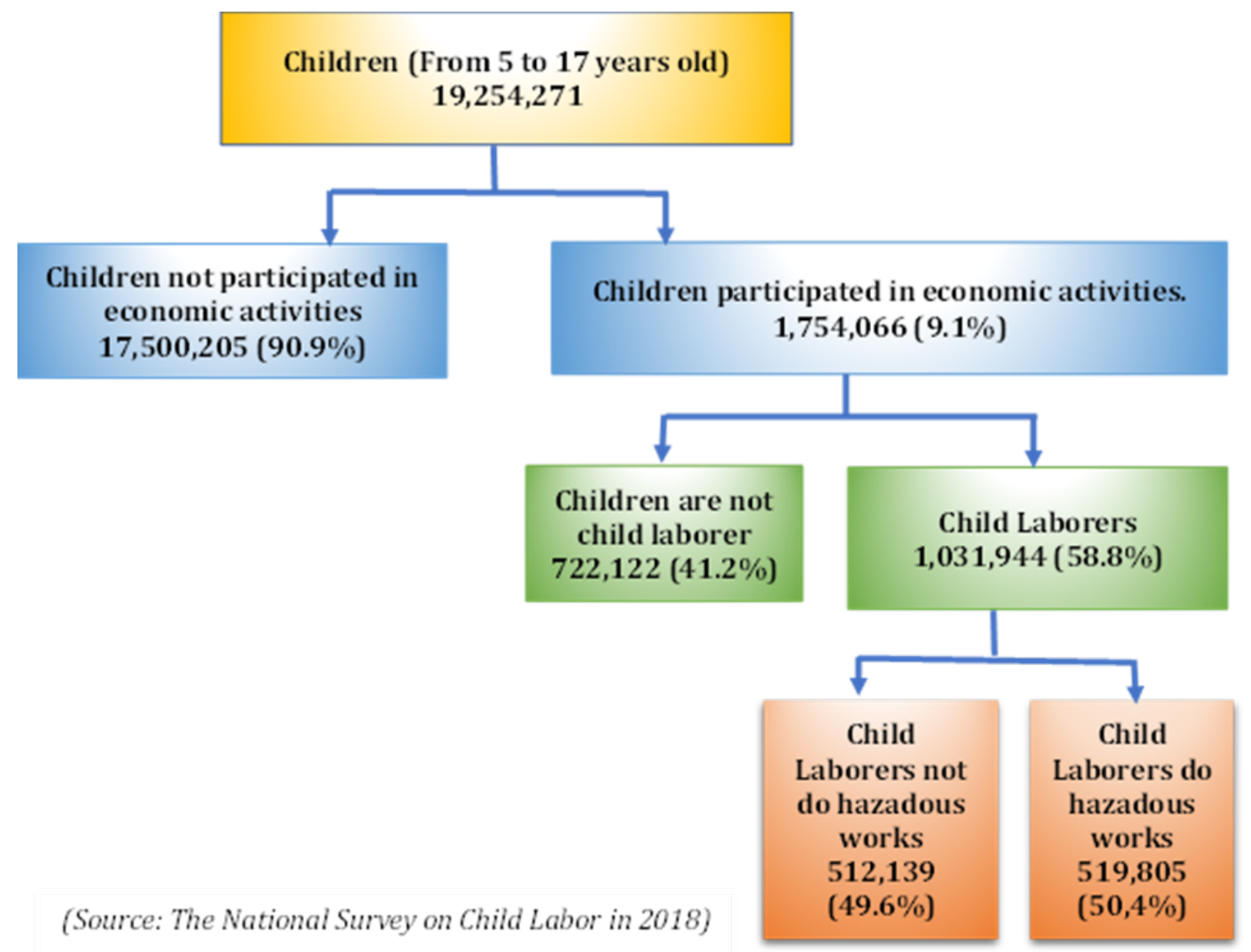

According to the above figure, most child laborers in Vietnam were aged from 5 to 17 . There were $84 \%$ child laborers located in rural areas, which was higher 2.5 times than the rate in the city. In terms of child laborers in hazardous works, more than one a half of child laborers had been working in the dangerous environment, with $50.4 \%$ of child laborers. Although the rate of child laborers in cities was lower than in rural areas, the rate of child laborers doing hazardous jobs in cities was higher than in rural areas. Most child laborers had engaged in labor from 12 years old, accounting for 53.4\%. However, the age group under 10 years old was still high level with $10.3 \%$. Mainly, there is $3.5 \%$ of child laborers under the $5-7$ age group.

Child laborers tend to withdraw from agricultural areas and increase in industry, construction, and service areas. The proportion of child laborers in agricultural, industrial and construction, and service areas was 53.6\%, $23.7 \%$, and nearly $21 \%$, respectively. Some attracted the participation of child laborers the most, such as complex planting and feeding, forestry, fisheries, textile, handmade production by bamboo, wood production, 
construction, service on maintenance, car and motorbike reparation, and restaurant services. Overwork was a common phenomenon in child labor. There were $34.2 \%$ of child laborers whose working time was over 40 hours per week. The rate of children group under 15 years old was $12 \% .{ }^{14}$ It is an alarming rate and urgently needed reduction and prevention measures.

The working environment was another problem. Child laborers mainly engaged in the informal sector with self-employment and business stuff in households. Most of those jobs had not had a safe environment for child laborers. According to the statistics, there were $27.7 \%$ of child laborers working in dust, garbage, and smoke environment; $11.5 \%$ of them working in loud noise environments; nearly $11 \%$ of them working in places with temperature which was too hot or too cold; over $8 \%$ of them to be chemical exposure. The problem was more severe in the group at 15-17 years old. Also, the survey showed that nearly $10.5 \%$ of child laborers had ever had to carry heavy objects with a weight of over $30 \mathrm{~kg}$, and $9.1 \%$ of them had to operate production machinery. ${ }^{15}$

\begin{tabular}{lcc}
\hline \multicolumn{1}{c}{ Working environment } & Total & Percentage (\%) \\
\hline Dust, garbage, smoke & 286,253 & $70.7 \%$ \\
\hline Gas, flammable substances, explosives & 26,069 & $83.9 \%$ \\
\hline Loud noise & 119,363 & $60.2 \%$ \\
\hline Temperature too hot or too cold & 111,927 & $80.7 \%$ \\
\hline Working underground/capes/tubes & 3,097 & $95.9 \%$ \\
\hline Working at high places & 25,554 & $74.6 \%$ \\
\hline Working underwater & 33,373 & $75.5 \%$ \\
\hline Working places is too dark, cramped & 10,642 & $70.4 \%$ \\
\hline Chemistry & 82,860 & $20 \%$ \\
\hline Addictive substances & 749 & $87.6 \%$ \\
\hline Construction site & 33,702 & $91.1 \%$ \\
\hline Sites for smithy, mechanics, metal casting & 6,765 & $85.1 \%$ \\
\hline Alcohol, cigarette production & 4,024 & $74.1 \%$ \\
\hline Other & 10,266 & $65.9 \%$ \\
\hline
\end{tabular}

Table 1. The working environment of children group at 15-17 years old ${ }^{16}$

\footnotetext{
14 Ibid.

15 Ibid.

16 The National Survey on Child Labor in 2018.
} 
Child laborers in Vietnam had to face many negative impacts on their physical health while working in an unsafe environment. It was estimated about $13.3 \%$ of child laborers had a skin wound ever, and $4 \%$ of them had dislocation or sprain. The group felt the risk of health and unsafe working environment from 15 to 17 years old. In addition, half of them continued to attend school, $48.6 \%$ dropped school, and $1.4 \%$ never went to school. When they were more grown-up, the rate tended to increase. This figure in hazardous working environments was $60 \%$, and about $1.4 \%$ of them have never gone to school.

\section{B. The Link of Child Labor and Poverty}

On the one hand, it is reported that poverty is the main cause of child labor. The data show that the link between child labor and poverty through evaluating finance state of households. Accordingly, the rate of poor households in rural areas is $8.3 \%$ which is 5.5 times higher than in urban areas. ${ }^{17}$ It explains why the rate of child labor in rural areas is higher than in urban areas. The main reason which forces them to engage in labor is to make income. It is nearly $30 \%$ of child laborers to decide to become a worker to make money. ${ }^{18}$ This rate tends to increase in the age group from 15-17 with 40.1\%. ${ }^{19}$ The motivations of child laborers engaging in hazardous works are mainly making income for themselves and their families. Particularly, 44.7\% of child laborers from 15 to 17 years old get dangerous jobs due to income-earning. ${ }^{20}$ The interesting aspect is that there are more than $40 \%$ of hazardous works are in households. ${ }^{21}$ It means that most child laborers doing hazardous works are household laborers, not salaried workers as previously thought.

\footnotetext{
17 Ibid.

18 Ibid.

19 Ibid.

20 Ibid.

${ }^{21}$ Ibid.
} 


\begin{tabular}{lcc}
\hline \multicolumn{1}{c}{ Motivations } & Total & $\%$ \\
\hline Making income for themselves & 95,956 & 9.3 \\
\hline Making income for their family & 213,319 & 20.7 \\
\hline Desire to participate in the business of households & 281,651 & 27.3 \\
\hline Desire to learn a job, get a job & 32,549 & 3.2 \\
\hline Dropping school & 68,688 & 6.7 \\
\hline Other & 11,561 & 1.1 \\
\hline Cannot identify & 328,220 & 31.7 \\
\hline
\end{tabular}

Table 2. Motivations for child labor ${ }^{22}$

Another research on child labor in Vietnam published in 2019 showed a link between child labor and the income rate of households. Accordingly, the rate of child labor with the lowest living standard is $33.9 \%$, while this rate decreased at $13.2 \%$ in the group with average living standards. It means that poor households typically have less ability to create the source for themselves. Thus, it increases the ability to mobilize children to make additional income for their families. ${ }^{23}$

Awareness of parents on children taking part in economic activities is a decisive factor in becoming laborers. There was over $57 \%$ of them did not allow their children to do any works. About $41.8 \%$ of them have an opposite opinion that lets their children do some suitable jobs if they do not negatively affect children's health and education. Under $1 \%$ of them allow children to do any employment, or they cannot give answers due to the lack of knowledge about child labor at the time of the survey.

Generally, poverty is the driving factor that forces children to work. If children grow up in a low-income family, they are more likely to become poor than any other normal child. As children grow up in a povertystricken environment, no essential demands will suffer the consequences in adulthood and the future. They include poor health, poor nutrition, school out, mental health problems, low self-esteem, discrimination, violence, little chance of getting a job to ensure a stable income. As a result, poverty

22 The National Survey on Child Labor in 2018.

23 Tran Quy Long, "Các yếu tố ảnh bưởng đến tình trạng lao dộng trẻ em Việt Nam" (2019) 2:101 Human Journal 32-43. 
locked them in a world where they could not reach their full potential and seize opportunities to contribute to society and the economy. ${ }^{24}$

On the other hand, child labor contributes to dropping out of school, making it more difficult for them to break the vicious cycle of poverty. In other words, child labor is the symptom of poverty. ${ }^{25}$ Under the National Survey 2018, 1,076,050 children from 5 to 17 years old do not go to school, accounting for $5.6 \%$ of the total population. ${ }^{26}$ There were many reasons for dropping school. The highest rate was the figure of 15-17 aged group with $18.3 \%{ }^{27}$. Over $44.8 \%$ of children aged $5-17$ years old do not like to go to school. ${ }^{28}$ But the alarming point is that over $15 \%$ of children drop school due to making income for themselves and their families or actively engaging in household business activities. ${ }^{29}$ Also, there was $14.4 \%$ of them unaffordable to pay tuition fees. ${ }^{30}$ In $1,031,944$ child laborers in Vietnam, half of them continued to attend school while over $48 \%$ had gone out of school and $1.4 \%$ had never gone to school. ${ }^{31}$ The rate of children who dropped school at 15 to 17 was the highest, with $75.8 \%{ }^{32}$ Even though child laborers go to school, the work had influenced negatively on the result of studying. ${ }^{33}$ However, many factors impact children's schooling decisions,

${ }^{24}$ UNICEF, Poverty Reduction Begins with Children (UNICEF, 2000).

25 Eric V Edmonds \& Nina Pavcnik, "Child Labor in the Global Economy" (2005) 19:1 Journal of Economic Perspectives 199-220.

${ }^{26}$ International Labor Organization, General Statistic Office \& Ministry of Labor, War Invalids and Social Affairs, supra note 11.

${ }^{27}$ International Labor Organization, General Statistic Office and Ministry of Labor, War Invalids and Social Affairs (10).

28 Ibid.

${ }^{29}$ Ibid.

${ }^{30}$ Ibid.

31 Ibid.

${ }_{32}$ Ibid.

${ }^{33}$ Huong Thu Le \& Ross Homel, "The impact of child labor on children's educational performance: Evidence from rural Vietnam" (2015) 36 Journal of Asian Economics 113. 
such as parents' education level or genders, or cultural elements. ${ }^{34}$ It means that child labor is only one of them.

An empirical study showed that attending school is linked with child labor. Over one a half of children who are not going to school become laborers, while this rate of children going to school to become workers is only $13.6 \%{ }^{35}$ It means that children who are not attending school must take part in the labor market at an early age, but they only take care of jobs at manual levels due to the lack of knowledge, skill, and health. If their education level is higher, they can find better decent works to get out of poverty.

Under the report on Multidimensional Poverty in Vietnam In 2018, education and vocation have significant impacts on employment and income of households. It showed that the multidimensional poverty rate in households whose heads were not graduated from primary school was $26.6 \%$ in 2016 . This figure was only under $1 \%$ in households in which the authorities graduated university or colleges. ${ }^{36}$ Also, the households in the agriculture area hold the highest multidimensional poverty rate, and then the second position was households in which the heads were not vocational.

According to the report on children outside school in 2016, it showed that becoming a laborer at an early age continued to become a factor in preventing children go to school. ${ }^{37}$ Forcing to make income for families was one of the reasons had children were left out of school. As a result, they had less time for studying made them bored of learning, and they dropped out of school forever. They had to do seasonal jobs, which led to

34 Diane L Putnick \& Marc H Bornstein, "Is child labor a barrier to school enrollment in low- and middle-income countries?" (2015) 41 International Journal of Educational Development 112-120.

35 Tran Quy Long, supra note 21.

36 UNDP, "Vietnam Academy of Social Science and Ministry of Labor, War Invalids and Social Affairs, Multidimensional Poverty in Vietnam - Reducing Poverty in All Its Dimensions to Ensure a Good Quality Life for All", online: <https:// www.vn.undp.org > docs > MDP-full-E>.

37 Ministry of Education and Training \& UNICEF, Report on Out-of-school Children 2016 (2016). 
temporary absences from school, and they could not follow the education programs as coming back.

This effect also occurs in the group of ethnic minorities in Vietnam. Under survey on multidimensional poverty in children in mountainous and remote areas in 2007 and 2012, the rate of ethnic minority children having to work at an early age was over three times higher than the rate in children group which is not an ethnic minority. ${ }^{38}$ It is also reported that child labor tends to decrease due to about $80 \%$ of households was improved income and other living conditions. ${ }^{39}$ Also, there seems to be a certain relationship between poverty and the consequences of natural disasters and climate change in mountainous ethnic minority areas. They must struggle to get out of poverty under very unfavorable conditions. Their livelihood is mainly based on agricultural and forestry production, which is a slow profitable field. Climate change is causing more and more extreme weather phenomena, making agroforestry production more and more at risk. These become challenges for ethnic minorities in the process of hunger eradication and poverty reduction. Ethnic minority and mountainous areas have complicated, dangerous, and fragmented terrain, poor infrastructure, limited transportation, frequent natural disasters, with common types such as droughts, storms, floods, landslides, pipe floods, flash floods, cyclones, hail, damaging cold, and saltwater intrusion.

\section{POLICIES TO REDUCE CHILD LABOR AND POVERTY IN VIETNAM}

\section{A. An Overview of Child Labor Regulations}

Vietnam is considered a country that actively joins in and ratifies many international treaties and promulgates many legal documents to eliminate and prevent child labor in general and reduce and alleviate poverty to combat child labor in particularity. To date, there are 25 in the total of 190

\footnotetext{
38 UNICEF and Ethnic Committee, "Multidimensional Child Poverty of Ethnic Minority Children - Situation, Dynamics, and Solutions," online: <https://www.unicef.org/ vietnam/reports/multidimensional-child-poverty-ethnic-minority-children $>$.

39 Ibid.
} 
ILO conventions ratified by Vietnam. There are $7 / 8$ basic international conventions and five conventions directly related to child labor. ${ }^{40}$ On February 20, 1990, Vietnam ratified the United Nations Convention on the Rights of the Child.

This action expressed strong statements of the Vietnamese Government in preventing children from any type of "economic exploitation" and protecting all rights of children for their better future. Then, the ILO's Convention No. 182 on the prohibition and immediate actions to eliminate the worst forms of child labor was continuously ratified by Vietnam on November 17, 2000. It required that the worst form of child labor be eliminated effectively with immediate and comprehensive actions, including providing a free primary education system, helping them get out of all the worst jobs, and reintegrating into society. ILO's Convention No. 138 on "the minimum age of employment," adopted on July 26, 1973, ratified by Vietnam on July 24, 2003. It required Vietnam to determine the age of children, the minimum age for work and set up national policies on eliminating child labor. In 2007, Vietnam joined the Compulsory Labor Convention 1930 (No.29). Accordingly, compulsory labor is defined as all work or services exacted from any person under the menace of any penalty. The said person has not offered bimself voluntarily. The year 2020 was when the Vietnamese National Assembly passed Convention No.105 on "Abolition of Compulsory Labor," $1957 .{ }^{41}$

Ratification of Vietnam on two conventions is predicted to contribute to preventing workers from risks of forced labor. It also helps to maintain a safe working environment which leads to practical impacts on labor productivity and creates advantages for Vietnamese goods in accessing international markets for sustainable development. Generally, the join of Vietnam in some basic conventions on child and child labor rights has been shown its legal responsibility with the international community in the fight

40 International Labour Organization, "International labour standards in Viet Nam," online: <https://www.ilo.org/hanoi/Areasofwork/international-labour-standards/lang --en/index.htm >.

41 Bill No. 29, Forced Labour Convention, 1930. 
against all forms of child labor abuse, forced child labor, or compulsory child labor.

In terms of domestic regulations, the document with the highest legal effect on child labor is the Constitution 2013. Its Article $37 \S 1$ strictly forbids infringe, torture, mistreat, neglect, abuse, exploit labor, and other acts that violate children's rights. The Act No.102/2016/QH13 on children - the basic law on children's rights, regulates explicitly prohibition of child exploitation, clearly definite responsibilities of ministries, agencies, social organizations, enterprises, families, communities in prevention and reduction of child labor. The Labor Code No. 45/2019/QH14 regulated age, working hours, workplaces of juvenile workers (Article 144, 145, 146, 147). Employing a person under 16 years old to take dangerous works or hazardous substance exposure shall be considered a crime under the Criminal Code No.100/2015/QH13 (amended and supplemented in 2017) (Article 296).

A list of jobs and workplaces where child labor is prohibited or allowed to recruit persons under 15 years old will be noticed by the competent authorities under Law No.84/2015/QH13 on Occupational Safety and Health and Circular No.09/2020/TT-BLĐTBXH on November 12, 2020, on guiding the Labor Code on juvenile workers. The Act on Handling Administrative Violations No. 15/2012/QH13 (the last amended in 2020) provided inspection, supervision, and handling violations of children's rights. Moreover, Vietnam has been enacted some legal documents related to implementing 13 goals and 40 targets on children in Vietnam's sustainable development goals by 2030, including the Decision No. 622/QĐ-TTg dated May 10, 2017, on promulgating the National Action Plan to implement the 2030 Agenda for Sustainable Development, ${ }^{42}$ and Decision No.681/QĐ-TTg dated June 4, 2019, on promulgating the road map to implementing sustainable development goals in Vietnam by $2030 .{ }^{43}$

42 Decision No. 622/QD-TTg on the National Action Plan to implement the 2030 Agenda for Sustainable Development, 2017.

43 Decision No.681/QĐ-TTg on the roadmap to implementing sustainable development goals in Vietnam by 2030, 2019. 
On May 27, 2021, the Prime Minister issued Decision No. 782/QĐ-TTg on approving the program to prevent and reduce illegal child labor for 2021-2025, with a vision to $2030 .{ }^{44}$ The program's objective is to prevent, detect, support, and intervene with children doing illegal work and children at risk of becoming child labor; strive to reduce the rate of child and juvenile labor from 5 to 17 years old to $4.9 \%{ }^{45}$ To achieve the above targets, the program sets out specific tasks such as completing policies and laws on preventing and reducing child labor. They include enhancing communication, education, and social mobilization to raise awareness and responsibility for preventing and reducing child labor and improving authorities' capacity at all levels, relevant agencies, organizations, and individuals, especially employers, in preventing and reducing child labor. It is a manifestation of the political determination of the Government for a better future for children and not to let them fall into poverty.

The first target is preventing, detecting, supporting, and intervening in child labor and children at risk of becoming child laborers. It strives to reduce the rate of child and juvenile laborers from 5 to 17 years old to $4.9 \%{ }^{46} 100 \%$ of children at risk of becoming child laborers and children trafficked for labor exploitation shall be supported, intervened, managed, and monitored timely. ${ }^{47}$ Over $90 \%$ of children at risk of becoming child laborers and child workers have access to appropriate education and vocational training programs. ${ }^{48}$

Secondly, it mentioned the dissemination of the prevention and reduction of child labor. The content of this goal is to ensure $90 \%$ of staff and teachers and $70 \%$ of parents and caregivers to be provided information and knowledge about preventing and reducing child labor. ${ }^{49}$ Moreover, $70 \%$ of children and $90 \%$ of enterprises, cooperatives, households, especially small and medium-sized enterprises, cooperatives, and households in craft

${ }_{44}$ Decision No. 782/QĐ-TTg on the program to prevent and reduce illegal child labor for 2021-2025, with a vision to 2030, 2021.

45 Ibid.

46 Ibid.

47 Ibid.

48 Ibid.

49 Ibid. 
villages are provided with information and knowledge on preventing and reducing child labor. ${ }^{50}$

Thirdly, it mentioned training on prevention and reduction of child labor. The target to be achieved is $90 \%$ of provincial and district civil servants and $70 \%{ }^{51}$ of commune officials of related competent authorities to be trained in knowledge and skills on management, prevention, detection, support, and intervention of child labor. About $90 \%$ of enterprises, ${ }^{52}$ especially small and medium enterprises; and $70 \%$ of cooperatives and households, ${ }^{53}$ especially cooperatives and households in craft villages, are trained in knowledge and skills on prevention, detection, support, and intervention of child labor. With the above objectives, the orientation towards 2030 strives to reduce the rate of children at the age from 5 to 17 years old to $4.5 \%,{ }^{54}$ and to reduce the proportion of hazardous child laborers at a minimum.

The program also mentioned some solutions to implement the above goals effectively. It requires the need to complete policies and laws on the prevention and reduction of child labor. On that basis, research and develop criteria for identifying child labor, building an inter-sectoral coordination mechanism to prevent and reduce child labor in the region's scope, and international cooperation. Raising awareness of stakeholders and improving the capacity of competent authorities are also crucial in the program. In particular, it focuses on how to strengthen inspection and examination of law and policies.

Some sectors and activities get special attention, including agriculture, handicrafts, services; preventing and combating crimes of trafficking in children for labor exploitation; developing networks for prevention, detection, support, and intervention of child labor and children at risk of becoming child labor; supporting child laborers, children at risk of becoming child labor and their families to access appropriate policies for poverty reduction, social security, education, and vocational training. It also

\footnotetext{
50 Ibid.

51 Ibid.

52 Ibid.

53 Ibid.

${ }^{54}$ Ibid.
} 
develops models to prevent and reduce child labor. Thus, the Vietnamese Government recognized and reported that poverty reduction is one of the measures to reduce child labor.

\section{B. Policies on Poverty Reduction}

For many years, Vietnam has promulgated a vast number of support policies for poor households to improve their income and enhance their ability to access basic social services. Some of which are Law on Employment in 2013 providing regulations on employment creation for vulnerable groups, including poor households; Law on Education 2019 and Law on vocational Training in 2014, regulated on tuition fees supports for children in poor households; Decree No. 20/2021/NĐ-CP on social support policies for poor households.

In particular, Vietnam issued the National Programs on Sustainable Poverty Reduction from 2016 to 2020 under Decision No. 1722-QĐ/TTg. The programs have five plans, including Projects No. 30a (Resolution No. $30 \mathrm{a} / 2008 / \mathrm{NQ}-\mathrm{CP})$, to reduce poverty sustainably in poverty districts. The Project No.135 for developing economy in mountainous areas and ethnic minority areas; project to support developing production, diversify livelihoods, and replicate the poverty reduction model in remained areas; the project for reducing poverty on information and communication; the project for enhancing the ability to supervise and evaluate the programs. In addition, some of the other action plans are Resolution No 100/2015/QH13 of the National Assembly dated November 12, 2015, on approving investment policy of the National Target Programs from 2016 to 2020; Resolution No. 76/2014/QH13 of the National Assembly on June 24 , 2014, on accelerating the implementation of the target of rapid and sustainable poverty reduction by 2020; Resolution No.80/NQ-CP of the Government on May 19, 2011, on sustainable poverty reduction orientation for the period from 2011 to 2020; Resolution No.24/2021/QH15 of the National Assembly on July 18, 2021, on approving investment policy of the National Target Program for sustainable poverty reduction for the period from 2021 to 2025. Most of 
them provide essential policies to help the poor households increase their income by themselves and improve their ability to access basic social services such as education, healthcare, water services, and electronic services.

A preferential loan mechanism is a popular legal tool to help poor households increase their income. According to Decree No. 78/2002/NĐ$\mathrm{CP},{ }^{55}$ poor households support preferential loans to do business, create employment, and pay tuition fees for children. The data showed that in 2016 there were over 2.297.000 households, and over 74,000 students enjoyed such loans with a total of 55,150 billion VND. ${ }^{56}$ It found that preferential loan mechanisms had positive impacts on poverty reduction. ${ }^{57}$ However, the disadvantage of this mechanism is that it has not been performed concurrently with and connected to other policies such as market promotion, employment creation, and vocational training. The mechanism has not brought long-term benefits to poor households to break the cycle of poverty due to the lack of guidance for borrowers on using such loans most effectively. ${ }^{58}$ Even though the higher number of economic activities households have, the more probability for children to work. ${ }^{59}$ Then, starting or expanding a business activity of households after getting preferential loans can lead to a labor shortage and raise the demand for child labor. ${ }^{60}$ In addition, official credit had a significant impact on

55 Decree No. 78/2002/NĐ-CP on Credit for the poor and other beneficiaries, (December 2002).

56 UNDP, Vietnam Academy of Social Science \& Ministry of Labor, War Invalids and Social Affairs, supra note 34.

57 Tinh Doan, et al., "Impact of Household Credit on Education and Healthcare Spending by the Poor in Peri-Urban Areas, Vietnam" (2014) 31:1 Journal of Southeast Asian Economies 87-103.

58 Lan Thanh Nguyen, et al., "Access to Preferential Loans for Poverty Reduction and Rural Development: Evidence from Vietnam" (2018) 52:1 Journal of Economic Issues 246269.

59 Giang Thanh Long, et al., "Child labor in Vietnam: Issues and Policy Implication" (2021) 130 (2021) 106222 Children and Youth Services Review.

60 Thi Thu Tra Pham \& Kien Son Nguyen, "Does Microcredit Influence Parent's Decision to Send A Child to School or to Work? Evidence From Vietnamese Rural Households" (2019) 53:3 The Journal of Developing Areas. 
education and healthcare spending more than unofficial credit. $^{61}$ Furthermore, increasing parents' income does not reduce child labor and rising schooling attendance in any case. ${ }^{62}$ Thus, an effective financial mechanism to tackle child labor should be considered comprehensively with other policies such as vocational training, employment creation services of the state, and the negative impact of preferential loan mechanism.

To increase income, poor households are also provided employment, vocational training support. Indeed, Vietnam had promulgated the scheme on vocational training for rural laborers under the Decision No. 1956/QĐTTg of the Prime Minister. Accordingly, laborers in poor households enjoy financial support on short-term vocational training tuition fees and living expenses during training courses. After finishing the courses, they can get loans from the Employment National Fund to create employment by themselves. According to the statistics, for eight months in 2017, about 250,000 people supported primary vocational training courses that lasted three months. ${ }^{63}$ In practice, some activities such as non-farm activities, selfemployment, or wage employments hold a key role in reducing poverty. ${ }^{64}$

In addition, poor households are supported to access education and healthcare services. Vietnam's education support policies have been focused on dealing with the differences among social groups based on the multidimensional approach to reducing poverty. There are several education support mechanisms such as supporting finance directly for learners (scholarships, free tuition fee), education loans, investing in education infrastructure, and enhancing teacher ability. Under Decree No. 86/2015/NĐ-CP, children in poor households are exempted from tuition fees at kindergarten, primary and high schools. The data showed that in 2016 3.807.187 people enjoyed reducing or exempting tuition fees with a

61 Doan, Gibson \& Holmes, supra note 55.

62 Carol Ann Rogers \& Kenneth A Swinnerton, "Does Child Labor Decrease When Parental Incomes Rise?” (2004) 112:4 Journal of Political Economy 939-946.

63 UNDP, Vietnam Academy of Social Science \& Ministry of Labor, War Invalids and Social Affairs, supra note 34.

${ }^{64} \mathrm{Vu}$ Van Hung, "The Effect of Education on Poverty in Rural in Vietnam" 13:7 International Journal of Innovation, Creativity and Change 2020. 
value of over 5.600 .000 billion VND. ${ }^{65}$ Most of them focus on helping poor children overcome the barriers of poverty and poor infrastructure in remote areas to come to school. They also help poor households to lighten the pressure of education fees on their children. However, these policies have only focused on differences in education accession more than in education quality. Indeed, the Law on Education in 2019 as well as Resolution No. 29-NQ/TW dated November 4, 2013, of the 8th Central Conference of the XI term of the Socialist Party on basic and comprehensive education reform strategy, did not mention any solutions to tackle the difference in education quality for children. Moreover, public expenditure for children at the tertiary level was much higher than in primary school. As a result, many poorer children may not access higher education levels. ${ }^{66}$

Regarding healthcare services, parents' health status is still a significant factor in forcing children to participate in the labor market early. ${ }^{67}$ Under Decree No.146/2018/NĐ-CP, poor households get a free health insurance card. Under Law on Medical Insurance in 2008 (amended in 2014), they get $100 \%$ of health insurance benefits even though a medical examination is not done at the district and provincial level. ${ }^{68}$ People from poor households who receive inpatient treatment in public health units at the district level and above are supported with meals at a minimum of $3 \%$ of the general minimum salary/patient/day. ${ }^{69}$ In addition, poor patients are also supported with travel expenses from home to hospital and hospital to home under

65 UNDP, Vietnam Academy of Social Science, \& Ministry of Labor, War Invalids and Social Affairs, Multidimensional Poverty in Vietnam - Reducing poverty in all its dimensions to ensure a good quality of life for all (2018).

$66 \mathrm{Vu}$ Hoang Linh, "An Overview of Access to and Inequality in Education System of Vietnam" (2012) 19:1 Asia-Pacific Development Journal, online: <https://www. unescap.org/sites/default/files/chap-2-VuHoangLinh.pdf>.

67 Silvia Mendolia, et al., "The Impact of Parental Illness on Children's Schooling and Labor Force Participation: Evidence from Vietnam" (2019) 17:2 Review of Economics of the Household 469-492.

68 Law on Medical Insurance in 2008 (amended in 2014).

${ }_{69}$ Decision No. 14/2012/QĐ-TTg on medical examination and treatment for the poor. 
Decision No. 14/2012/QĐ-TTg on medical examination and treatment for the poor.

Then, households are beneficiaries in most of the policies to tackle poor children. Poor household is identified by criteria developed on a multidimensional approach. Specifically, under Decision No. 59/2015/QD-TTg dated November 19, 2015, standards of poor households, near-poor households include two cases. The first one is the poor household with an average income of is maximum of 700,000VND per month in rural areas and 900,000VND per month in urban areas. ${ }^{70}$ Or the second is a household with an average income of 700,000VND to $1,000,000 \mathrm{VND}$ per month in rural areas or $900,000 \mathrm{VND}$ to $1,300,000 \mathrm{VND}$ per month in urban areas and a lack of 3 or more indicators measuring ability to access basic social services. ${ }^{71}$ The basic social services include education, healthcare, housing, clean water and sanitation, and information.

\section{DISCUSSION AND POLICY RECOMMENDATIONS}

\section{A. Approaches in Policymaking}

Although Vietnam has relatively comprehensive legal regulations on child labor, there is no legal definition. Article 1 of the Act on Children in 2016 regulated a child as a person under 16 years old. Simultaneously, the Labor Code 2019 defines a worker as a person who works for an employer under an agreement, is remunerated, and is managed, directed, and supervised by an employer. These definitions assert that a child laborer under 16 years old works for an employer under a labor agreement. There are some exceptions in which the age of workers can be under 15 years old required by law.

In reality, the lack of definition of child labor dramatically affects promptly handling violations related to child labor. For example, in April 2018, a group of female ethnic minority children in Dak Nong province was illegally brought to Ho Chi Minh City. Although the local Government in

70 Decision No. 59/2015/QD-TTg.

71 Ibid. 
Ho Chi Minh city got the notification of Dak Nong province in advance, they could not detect such violations. Then, such children were rescued by Dak Nong province's competent authority and brought back home in July $2108 .^{72}$ It shows that local Government cannot control child labor as children. In turn, employers can find ways to evade the regulations, such as taking care of seasonal work or with short working time, taking part in works hidden behind vocational training programs, or changing working places when there is an inspection of the competent authorities. In addition, the lack of definition of child labor has also made child abuse in the informal sector and poor households in rural areas in Vietnam more serious. It is an area beyond the control of labor inspectors where unions do not exist to represent and protect workers' rights. As a result, detecting, discovering, and handling child labor cases in such sectors are challenged. Participating in age-appropriate works for children should be encouraged. However, it is necessary to regulate a clear explanation of child labor by law. Such regulations should be answered the main questions such as what age children are allowed to work? Which jobs can they do? How much time should they work? And where can they work?

The concept of child labor has been mentioned in many conventions and acts in many countries. Child labor is generally defined as work that deprives their childhood, potential, and dignity, harmful to physical and mental development. This definition showed aspects of child labor's impacts. The first problem is the harm to children's physical, mental, moral, and social life. The second point is that child labor has to interrupt children's schooling by keeping them out of school, forcing them to leave school early, and requiring them to combine school attendance with heavy work. ${ }^{73}$ It explained why the impact of child labor on education is always an essential factor that caused the poverty trap and maintained the cycle of poverty. Child labor also differs from the term "children engaged in economic

72 VOV, "Lao động trẻ em ở TP HCM, bài toán chưa có lời giải”, online: <https:// vov.vn/xa-hoi/lao-dong-tre-em-o-tp-hcm-bai-toan-chua-co-loi-giai-809178.vov>.

73 International Labour Organization, "Child Labour: a Textbook for University Students," online: <https://www.ilo.org/global/publications/books/WCMS_067258/lang--en/ index.htm>. 
activities" because child labor has a narrower meaning. It also excludes all children legally employed under ILO's conventions.

Child labor is referred to the works done by children under 14 years old and children aged from 14 to 17 years old who work in hazardous and arduous conditions. ${ }^{74}$ One example is the Fair Labor Standard Act 1938 of the USA (Chapter 33). Child labor is defined by describing the criteria of age, working hours, type of work, and which hazardous working environments are for children (person under 18 years old). Oppressive child labor is referred to any work under 16 years old engaged in any occupation required by an employer. In other words, child labor is an employer employs a person between the ages of 16 and 18 in any occupation which is considered particularly dangerous to the health or well-being of that person. ${ }^{75}$

Moreover, children's participation in the labor market significantly depends on the characteristics of households-the poor households. ${ }^{76}$ However, the system's weak point in poverty reduction policies is the lack of comprehensive notion and approach on poor children. For example, Resolution No.80/NQ-CP regulated orientations on sustainable poverty reduction from 2011 to 2020 mentioned policy framework for reducing poverty in Vietnam. However, there are not any contents mentioned poor children.

In addition, beneficiaries in most of the poverty reduction programs, plans, and policies are poor households, not poor children. It means that only children who are in poor households enjoy support policies. However, accessing support policies of children depends significantly on the decisions of their parents. As a result, it creates a vacuum of public policies for poor children due to the support of the State could be unable to reach beneficiaries. ${ }^{77}$ Thus, Vietnam needs a unified approach in policymaking

74 Ana C. Dammert, et al., supra note 8.

75 Fair Labor Standard Act, 1938.

76 Eric V Edmonds \& Maheshwar Shrestha, "The Impact of a Minimum Age of Employment Regulation on Child Labor and Schooling" (2012) 1:1 IZA Journal of Labor Policy 1-28.

77 UNICEF and Ethnic Committee, supra note 38. 
on poor children, ensuring children become directed beneficiaries in such policies. In other words, it should be based on a "Children-centered" approach in policymaking. In addition, in line with the reform orientations of poverty reduction policies, policies for poor children should be continuously reviewed and evaluated to eliminate overlaps and ineffectiveness in the short term. It should also be associated with strengthening public management, administrative procedure reform to enhance the ability of poor children to access support policies.

As mentioned above, school attendance is a significantly meaningful tool in reducing child labor. The human capital approach regards education as an essential instrument of the reduction of poverty. ${ }^{78}$ However, the choice of children going to school or working at an early age depends on the awareness of their parents. According to statistics, $67 \%$ of parents do not allow their children to do any works while $17.4 \%$ of them let their children do suitable works. ${ }^{79}$ The remaining proportion (15.6\%) of parents did not know how to decide at the survey time. ${ }^{80}$ In particular, there was $1 \%$ of them could let their children do any works. ${ }^{81}$ Also, the educational level of households holds a vital role in the working status of children aged 6-17 years old. ${ }^{82}$ The higher the household education level was, the lower probability for children going to work. ${ }^{83}$ In addition, the educational level of children is a significant factor to link with the probability children engages in economic activities. It is estimated to be about a 30\% lower probability of working for children with better education levels than those with lower education levels. ${ }^{84}$ On the other hand, the educational status of household heads is an essential factor in the link with the income of households. ${ }^{85}$ Thus, the matter here is how to increase the educational level

78 Jandhyala B G Tilak, "Education and Poverty" (2010) 3:2, 191-207 Journal of Human Development.

79 International Labor Organization, General Statistic Office \& Ministry of Labor, War Invalids and Social Affairs, supra note 11.

80 Ibid.

81 Ibid.

82 Giang Thanh Long, et al., supra note 59.

83 Ibid.

${ }^{84}$ Ibid.

85 Nguyen, et al., supra note 56. 
of both children and their parents. Education support of the State should be a pioneering policy in eliminating and preventing child labor. The State has to ensure a comprehensive, equitable, and affordable education system to combat child labor. ${ }^{86}$

Regarding ethnic minority children, it is necessary to have appropriate mechanisms and policies to help them and their family to turn challenges into opportunities through improving their ability to adapt to climate change, actively transforming the labor structure, diversifying livelihoods to achieve sustainable development goals, and above all, will influence addressing child labor. It is necessary to improve the socio-economic life of the community, especially in ethnic minority areas, poor areas, and disadvantaged areas, through hunger eradication and poverty reduction programs, and other programs related to employment, health care and better population work, family planning. Economic policies to get rid of poverty should be likely to have many effects on addressing child labor. ${ }^{87}$

\section{B. Action Plans and Law Enforcement Capacity}

In the context of the inconsistent security system and hierarchy administration, Vietnam should set up action plans for preventing and eliminating child labor through reducing poverty. All stakeholders should participate in the plans, including the state, enterprises, families, civil society, employees, employers, and international organizers. They should focus on raising the awareness and capacity of all stakeholders in abolishing child labor. It also provides support for children and their families to prevent them from poverty.

The first is setting up a unified program on poverty children reduction and building a legal institution on coordination among competent authorities. Indeed, many poor reduction programs oversee competent differential authorities, but they lack coordination, making such programs ineffective.

86 OECD, Child Labour: Causes, Consequences and Policies to tackle it (2019).

87 Lan Truong Thi, "Xóa bỏ lao động trẻ em: Kinh nghiệm ở một số quốc gia và giá trị tham khảo cho Việt Nam" (2019) State Management Review. 
There are about 52 policies and programs on poverty reduction. ${ }^{88}$ Although the poor children are the matter which needs a multidimensional approach in making policies, the existence of many programs easily leads to overlap in targets, beneficiaries, management, and law enforcement. Thus, it is necessary to review and simplify poverty reduction programs. It needs a legal mechanism that is strong enough to coordinate among ministries, local agencies, and social organizations to overcome inadequacies in the current system of poverty reduction policies.

It is also reported that the more poverty reduction programs were built, the fewer financial resources were allocated for such programs. Most poverty reduction programs have been allocated unaffordable finance resources. The National Goal Program on Education from 2012 to 2015 was the only exception as it was invested public budget with a percentage of $85 \% .{ }^{89}$ This rate in other sectors was in the range of $16-31 \% .{ }^{90}$ Thus, Vietnam should review the measures to allocate financial resources of poverty reduction programs towards allocating resources in the medium and long-term, instead of doing in short-term as now. It should review and unify poverty reduction programs to prevent fragmentary policies, resource dispersions, and ineffective capital management in the context of economic crisis due to COVID-19 and decreased external aids. It should be based on the reform approach of the social assistance system in general, that is, converting the unconditional supports to conditional supports. Accordingly, the State budget will only pay partially. The rest will be contributed by its citizens. This solution helps to reduce the financial burden on the State budget in allocating resources to poverty reduction programs and avoiding the poor's dependence on the State's supports.

Secondly, the motivation of business establishments in using child labor is profitable, ${ }^{91}$ thus one of the best solutions for preventing child labor is increasing their legal awareness. In reality, it is challenged to eliminate

${ }^{88}$ UNICEF and Ethnic Committee, supra note 38.

89 Ibid.

90 Ibid.

91 Zehra F Arat, "Analyzing Child Labor as a Human Rights Issue: Its Causes, Aggravating Policies, and Alternative Proposals" (2002) 24:1 Human Rights Quarterly 177-204. 
child labor in developing and underdeveloped nations, especially in many poor households in rural and mountainous areas like Vietnam. On the one hand, acknowledging the negative consequences of illegal recruitment of child labor has them said "No" to providing child labor. On the other hand, such action helps to improve the notion of parents to force children to work early, particularly in rural, remote areas. Mainly, child labor is one of the main commitments of Vietnam in some FTAs, such as the Comprehensive and Progressive Agreement for Trans-Pacific Partnership (CPTPP), and the EU-Vietnam Free Trade Agreement (EVFTA). It means that if business establishments do not strictly comply with such commitments, they will face the risk of violating the labor standards, directly affecting their market share, reputation, and competitive advantages of Vietnam in general. Therefore, this solution helps employers be aware of child labor and follow strict standards of these agreements. Practically, many enterprises contribute directly or indirectly to the increase of illegal child labor. For instance, many enterprises have directly recruited child labor or know, approved, and agreed to cooperate with partners/suppliers who recruited child labor in production and business activities. ${ }^{92}$ Another example is that many agricultural households in Vietnam could not earn income from fishing because business activities polluted the rivers. As a result, they must force their children to go to workplaces.

Thus, guideline materials or handbooks on protecting children from child labor should be compiled for business units. For instance, "Guidelines for the prevention and reduction of child labor for businesses" was prepared by the Vietnam Chamber of Commerce and Industry based on the guidelines of the Program International on the Elimination of Child Labor (ILO IPEC) and updated in line with the reality of Vietnam. It provides basic knowledge on identifying child labor, suggests practical actions to respond to the risks of child labor utility, and provides an understanding of the benefits of preventing and reducing child labor in business activities. Another example is the guidelines of Children's rights in policies and codes

${ }^{92}$ International Labour Organization \& Vietnam Chamber of Commerce and Industry, Hướng dẫn phòng ngùa và giảm thiểu lao dộng trẻ em dành cho Doanh nghiẹpp (2020). 
of conduct: a tool for businesses produced by UNICEF in collaboration with Save the Children. ${ }^{93}$ Those are effective information channels for employers to convert regulations on children's rights into the company's policies. Additionally, the code of conduct helps people in business respect children's rights and promote them in compliance with its core business.

Thirdly, the awareness of households and children on child labor is a challenge since they do not know about their rights to enjoy a safe working environment, access to legal protection, and propaganda activities. Thus, public programs should propagandize them to understand their rights and provide support mechanisms to protect such rights.

\section{CONCLUSION}

The child labor status in Vietnam proved that poverty is the main cause of child labor. In turn, child labor shortens the time to get an education, reduces opportunities to get better jobs, and exacerbates poverty. In Vietnam, regulations on child labor are based on international commitments of Vietnam and ensuring law enforcement. In contrast, rules on poverty reduction have built a public support system for poor households such as finance, education, and employment. However, the lack of a comprehensive approach in making law enforcement policies and inefficiencies has made child labor reduction by reducing poverty not yet achieve the desired results. In the context of integration and the COVID19 pandemic, it is confirmed once again that combating child labor significantly depends on how governments deal with poor children and poor households. It requires a clear and unified legal system based on a children-center approach to tackle poverty and overall action plans with the participation of all stakeholders in preventing and reducing child labor in the coming time.

93 United Nations International Children's Emergency Fund - UNICEF \& Save the Children, Quyền trẻ em trong các chinh sách và quy tắc úng xử công cụ dành cho các doanh nghiẹp (2013). 


\section{ACKNOWLEDGMENTS}

None.

\section{COMPETING INTERESTS}

The authors declared that they have no competing interests.

\section{REFERENCES}

Heywood, Colin, A History of Childhood: Children and Childhood in the West from Medieval to Modern Times (John Wiley \& Sons, 2013).

Arat, Zehra F, "Analyzing Child Labor as a Human Rights Issue: Its Causes, Aggravating Policies, and Alternative Proposals" (2002) 24:1 Human Rights Quarterly 177-204.

Doan, Tinh, et al., "Impact of Household Credit on Education and Healthcare Spending by the Poor in Peri-Urban Areas, Vietnam" (2014) 31:1 Journal of Southeast Asian Economies 87-103.

Edmonds, Eric V \& Nina Pavcnik, "Child Labor in the Global Economy" (2005) 19:1 Journal of Economic Perspectives 199-220.

Edmonds, Eric V \& Maheshwar Shrestha, "The impact of a minimum age of employment regulation on child labor and schooling" (2012) 1:1 IZA Journal of Labor Policy 1-28.

Giang Thanh Long, et. al., "Child Labor in Vietnam: Issues and Policy Implication" (2021) 130 (2021) 106222 Children and Youth Services Review.

International Labour Organization, "2021: International Year for the Elimination of Child Labour", online: <https://www.ilo.org/global/ about-the-ilo/newsroom/news/WCMS_766351/lang--en/index. htm>.

International Labour Organization, "Child Labour: a Textbook for University Students," online: <https://www.ilo.org/global/publications/books/W CMS_067258/lang--en/index.htm>.

International Labour Organization, "International labour standards in Viet Nam," online: <https://www.ilo.org/hanoi/Areasofwork/internationallabour-standards/lang--en/index.htm >. 
International Labour Organization "Modern slavery and child labour - 40 million in modern slavery and 152 million in child labour around the world", online: <https://www.ilo.org/hanoi/Informationresources/ Publicinformation/newsitems/WCMS_574717/lang--en/index.htm>.

Jandhyala B G Tilak, "Education and Poverty" (2010) 3:2, 191-207 Journal of Human Development.

Le, Huong Thu \& Ross Homel, "The impact of child labor on children's educational performance: Evidence from rural Vietnam" (2015) 36 Journal of Asian Economics 1-13.

Mendolia, Silvia, et al., "The impact of parental illness on children's schooling and labor force participation: evidence from Vietnam" (2019) 17:2 Review of Economics of the Household 469-492.

Nguyen, Lan Thanh, et al., "Access to Preferential Loans for Poverty Reduction and Rural Development: Evidence from Vietnam" (2018) 52:1 Journal of Economic Issues 246-269.

Pham, Thi Thu Tra \& Kien Son Nguyen, "Does Microcredit Influence Parent's Decision to Send A Child to School or to Work? Evidence From Vietnamese Rural Households" (2019) 53:3 The Journal of Developing Areas.

Putnick, Diane L \& Marc H Bornstein, "Is child labor a barrier to school enrollment in low- and middle-income countries?" (2015) 41 International Journal of Educational Development 112-120.

Rogers, Carol Ann \& Kenneth A Swinnerton, "Does Child Labor Decrease When Parental Incomes Rise?" (2004) 112:4 Journal of Political Economy 939-946.

Tran Nguyen Quang Ha, "The Impact Of Covid_19 On Child Labor In Vietnam" (2021) 24(3) Science \& Technology Development Journal 2044-2048.

Tran Quy Long, "Các yếu tố ảnh hưởng đến tình trạng lao động trẻ em Việt Nam" (2019) 2:101 Human Journal 32-43.

Truong Thi, Lan, "Xóa bỏ lao động trẻ em: Kinh nghiệm ở một số quốc gia và giá trị tham khảo cho Việt Nam" (2019) State Management Review.

VOV, "Lao động trẻ em ở TP HCM, bài toán chưa có lời giải", online: <https://vov.vn/xa-hoi/lao-dong-tre-em-o-tp-hcm-bai-toan-chua-coloi-giai-809178.vov>. 
$\mathrm{Vu}$ Hoang Linh, "An Overview of Access to and Inequality in Education System of Vietnam" (2012) 19:1 Asia-Pacific Development Journal.

Vu Van Hung, "The Effect of Education on Poverty in Rural in Vietnam" 13:7 International Journal of Innovation, Creativity and Change 2020.

Ana C Dammert et al., Effects of Public Policy on Child Labor Current Knowledge, Gaps, and Implications for Program Design (Research Support Team).

Heywood, Collin, "Child Labor" in Encyclopedia of European Social History Encyclopedia.com (2021).

ILO, Global Estimates of Child Labor (2017).

ILO \& UNICEF, Child Labour: Global Estimate, Trends and the Road Forwards (2020).

International Labor Organization, General Statistic Office \& Ministry of Labor, War Invalids and Social Affairs, Vietnam National Child Labour Survey 2018 - Key Findings (2020).

International Labour Organization - ILO \& Vietnam Chamber of Commerce and Industry - VCCI, Hướng dẫn phòng ngùa và giảm thiểu lao động trẻ em dành cho Doanh nghiệp (2020).

Ministry of Education and Training \& UNICEF, Report on Out-of-school Children 2016 (2016).

OECD, Child Labour: Causes. Consequences and Policies to tackle it (2019).

UN Committee on the Rights of the Child (CRC), Report of the UN Committee on the Rights of the Child: fourth session (September 20 to October 8, 1993), October 25, 1993, CRC/C/20 (1993).

UNDP, Vietnam Academy of Social Science \& Ministry of Labor, War Invalids and Social Affairs, Multidimensional Poverty in Vietnam Reducing poverty in all its dimensions to ensure a good quality life for all, by UNDP, Vietnam Academy of Social Science \& Ministry of Labor, War Invalids and Social Affairs (2018).

UNDP, Multidimensional Poverty in Vietnam - Reducing poverty in all its dimensions to ensure a good quality life for all, by UNDP, Vietnam Academy of Social Science, \& Ministry of Labor, War Invalids and Social Affairs (2018).

UNICEF, Poverty Reduction begins with Children (UNICEF, 2000). 
UNICEF \& Ethnic Committee, Multidimensional Child Poverty of Ethnic Minority Children - Situation, Dynamics, and Solutions (2016).

United Nations International Children's Emergency Fund - UNICEF \& Save the Children, Quyền trẻ em trong các chinh sách và quy tắc ưng xử công cu dành cho các doanh nghiệp, by United Nations International Children's Emergency Fund - UNICEF \& Save the Children (2013). 
502 Child Labor and Poverty Reduction in Vietnam: Issues and Policy Implications

This page intentionally left blank 